REMATIE DIE MUALIES

Campinas-SP, v.39, n.1, pp. 38-62, jan./jun. 2019

\title{
DO MUSEU COMO PRISÃO DE IMAGENS AO TRIUNFO DA CIDADE COMO OBRA DE ARTE TOTAL
}

\author{
From the Museum as a Prison of \\ IMAGES TO THE TRIUMPH \\ of The City as a Total Work of ARt
}

Marcio Seligmann-Silva ${ }^{1}$

\begin{abstract}
Resumo: O texto apresenta inicialmente a crítica de Paul Valéry aos museus, anotada em seu artigo de 1923, "Le problème des musées", que partia de um pressuposto que Benjamin posteriormente teorizou nos temos da arte aurática. Marcel Mauss e Bataille são introduzidos a partir da importância de suas ideias para se pensar a "virada etnológica" da nossa visão de arte e museu, que abalou a tradição estética eurocêntrica. Com Foucault pensa-se o museu como uma das figuras assumidas pela onipresença de heterotopias na modernidade. Recupera-se a reflexão de Adorno sobre os museus, inspirada em Valéry e em Proust, concluindo com sua tese, segundo a qual as artes se tornaram inscrições do sofrimento histórico. Retoma-se a gênese dos museus no século XIX como parte de uma ideologia ontotipológica, de criação da nação, do "próprio" em oposição ao "outro". Em seguida retoma-se a concepção de Benjamin para quem a tradição foi explodida pela reprodução técnica e foi sugada pelas imagens cinematográficas. Conclui-se com a teoria de Vilém Flusser do fim dos museus e do triunfo da cidade como obra de arte total, Gesamtkunstwerk. Nota-se que a estetização da sociedade moderna pode tanto assumir um caráter fascista, como um caráter emancipador. Tudo depende de a visão lúdico-crítica da arte conseguir vencer as forças da censura que querem seu aniquilamento e a imposição de um pensamento totalitário.

Palavras-chave: museu como prisão; arte e vida; obra de arte total.
\end{abstract}

1 Professor do Instituto de Estudos da Linguagem (IEL), Universidade Estadual de Campinas (Unicamp): <m.seligmann@uol.com.br > . 


\begin{abstract}
The text initially presents Paul Valéry's critique of museums, noted in his 1923 article "Le problème des musées", which started from a presupposition that Benjamin later theorized within the concept of "aura". Marcel Mauss and Bataille are introduced from the point of view of their importance to think the "ethnological turn" of our vision of art and museum, which shook the aesthetic Eurocentric tradition. With Foucault the museum is thought of as one of the figures assumed by the omnipresence of heterotopias in modernity. Recovering Adorno's reflection on museums, inspired by Valéry and Proust, the text retrieves his thesis that the arts have become inscriptions of historical suffering. The genesis of museums in the nineteenth century is resumed as part of an ontotipological ideology, of creation of the nation, of the "own" as opposed to the "other". Then it remembers the conception of Benjamin for whom the tradition was exploded by the technical reproduction and was sucked by the cinematographic images. It concludes with the theory of Vilém Flusser of the end of the museums and the triumph of the city as total work of art, Gesamtkunstwerk. It is noted that the aestheticization of modern society can either assume a fascist character or an emancipatory character. Everything depends on the ludic-critical vision of art to be able to overcome the forces of censorship that want its annihilation and the imposition of a totalitarian thought.
\end{abstract}

Keywords: Museum as Prison; Art and Life; Total Artwork.

"Todas as lendas, todas as mitologias e todos os mitos, todos os fundadores de religiões, e mesmo todas as religiões... aguardam sua ressurreição em celuloide, e os heróis precipitam-se aos portais." (Abel Gance, 1927 [apud BENJAMIN, 1935])

“[...] a cidade do futuro será a única 'obra de arte' [...] todos os cidadãos serão artistas”. (Vilém Flusser, [s.d.4, p. 4])

\title{
MUSEUS, ARQUIVOS, EMPRESAS COLONIAIS E SEPULCROS
}

"Não gosto muito de museus. Existem muitos admiráveis, não existe nenhum delicioso. As ideias de classificação, de conservação e de utilidade pública, que são justas e claras, têm pouco a ver com as delícias." (VALÉRY, 1960, p. 1.290).² Assim abriu, Paul Valéry, seu pequeno e bombástico texto "Le problème des musées", de 1923. O gabinete de pinturas do museu aparenta, para ele, "uma estranha desordem organizada” [un étrange désordre organisé] (p. 1.290). As esculturas disputam o espaço entre si e cada uma deseja a desaparição da outra. A dialética entre instrução e encantamento não se desdobra, e ele comenta: "A tristeza, a chateação, a admiração, o bom tempo

2 "Je n'aime pas trop les musées. Il y en a beaucoup d'admirables, il n'en est point de délicieux."

Remate de Males, Campinas-SP, v.39, n.1, pp. 38-62, jan./jun. 2019 - 39 
que fazia lá fora, as críticas de minha consciência, a terrível sensação do grande número de grandes artistas caminham comigo" (p. 1.291). ${ }^{3}$ Tudo é "fadiga" [fatigue], tudo é "barbárie" [barbárie] (p. 1.291). Tudo é incoerente: um retrato ao lado de uma marinha, de uma cozinha e de um triunfo. Ele compara a visita ao museu à audição de "dez orquestras ao mesmo tempo" [dix orchestres à la fois] (p. 1.291). As grandes civilizações da China, Egito e Grécia, não por acaso, não tinham esse disparate que são os museus. "Mais notre héritage est écrasant" [mas nossa herança é esmagadora] (p. 1.292), exclama o poeta, como que ecoando a crítica de Nietzsche ao excesso de história de sua consideração intempestiva, sobre As vantagens e desvantagens da História para a vida, de 1861. No museu ele se sente massacrado pela visão daquele acúmulo de obras-primas, que significam o amontoado em uma miríade de anos de trabalho, de pesquisa, de genialidade. Impossível receber tudo isso de uma vez. Sucumbe-se à "superficialidade”. Mas a outra resposta possível diante dessa concentração de saber decantado em maravilhas da arte - o tornarmo-nos eruditos -, também seria uma derrota, pois essa atitude não se volta ao mais delicado, muito menos ao essencial. Ela submete tudo à memória prodigiosa, eliminando outras leituras e a "presença do maravilhoso". Em suma, a erudição "anexa ao museu imenso uma biblioteca ilimitada. Vênus transformada em documento" (VALÉRY, 1960, p. 1.293). 4

Interessante pensar que essas observações são contemporâneas à Escola de Warburg, que justamente valorizava a "memória prodigiosa", e que erigiu um templo a essa memória justamente sob o signo da justificadamente famosa Biblioteca de Warburg, cuja entrada, em seu endereço londrino, ainda porta na sua fachada a inscrição em grego: "Mnemosyne". A Memória é a musa dessa influente linha de pensamento. Mas pode-se estabelecer uma mediação entre a postura "antiantiquaria" de Valéry e a de Warburg. Penso na postura herdada dos pais da história da arte, sobretudo de Winckelmann (1717-1768), que insistia quanto à necessidade de ver e aprender a arte antiga no seu meio próprio, original, autêntico. Esse mesmo Leitmotiv foi central trinta anos após a sua morte, quando Napoleão ordenou o transporte das principais estátuas greco-romanas de Roma para o Louvre. Quatremère de Quincy - um ferrenho

3 "La tristesse, l'ennui, l'admiration, le beau temps qu'il faisait dehors, les reproches de ma conscience, la terrible sensation du grand nombre des grands artistes marchent avec moi." 4 “[...] annexe au musée immense une bibliothèque illimitée. Vénus changée en document".

Remate de Males, Campinas-SP, v.39, n.1, pp. 38-62, jan./jun. 2019 - 40 
adepto das doutrinas de Winckelmann - nas suas Cartas a Miranda sobre a transferência dos monumentos artísticos da Itália (1796) falará desse país e sobretudo de Roma como um único museu que não poderia ter nenhuma de suas partes desmembrada. Uma obra isolada não significaria nada e murcharia como uma planta retirada do seu meio natural. Os artistas de toda a Europa deveriam ir a Roma aprender não apenas a grande arte, mas, sobretudo, passar pela escola da visão, educar o seu olhar através da "paisagem clássica", como o fizeram Goethe e tantos outros viajantes no século XVIII (SELIGMANN-SILVA, 2018, p. 291). Para Quincy (1989, p. 103), Winckelmann havia dado um "corpo" para a Antiguidade, que, até ali, teria sido apenas disjecti membra poetae: ou seja, Winckelmann teria reconstituído o corpo de Orfeu, o poeta-sacerdote que está na origem da cultura Grega. Por sua vez, Schiller escreveu o poema "Die Antiken zu Paris" [As antiguidades em Paris] em resposta a esse rapto das obras romanas. Nele o poeta afirma que as estátuas não descerão do seu pedestal para se encontrar com os parisienses: só quem possui o calor no seu coração poderia ter as Musas.

\section{MARCEL MAUSS E BATAILLE: A VIRADA ETNOLÓGICA DA VISÃO DA CULTURA/CIVILIZAÇÃO}

Essa nostalgia do "local de origem" das obras de arte também estava presente nos autores em torno da revista Documents, que sonhavam com um museu capaz de integrar o "valor de uso" de seu acervo (pensado sobretudo do ponto de vista etnológico e que deu origem ao Musée de l'Homme de Paris) e que não o massacrasse sob o peso de seu valor estético (HOLLIER, 2018, p. 12; LÉVI-STRAUSS, 1958, pp. 412-414). Não por acaso, as primeiras palavras do verbete "Museu" do dicionário crítico publicado na Documents, de autoria de Bataille, não guarda palavras lisonjeiras às origens do museu europeu: "Segundo a Grande enciclopédia, o primeiro museu no sentido moderno da palavra (isto é, a primeira coleção pública) teria sido fundado em 27 de julho de 1793, na França, pela Convenção. A origem do museu moderno estaria, assim, ligada ao desenvolvimento da guilhotina" (BATAILLE, 2018, p. 193).

Marcel Mauss (que também contribuiu para a revista Documents) foi um dos responsáveis pela moderna concepção do museu etnológico, na medida em que ensinava aos pesquisadores e coletores de objetos em países da África colonial francesa, que alimentariam os museus/arquivos, a se interessarem por todo e qualquer objeto, programaticamente 
desconstruindo um ideal estético eurocêntrico ("Ne jamais chercher l'effet esthétique" [Nunca procure o efeito estético] - MAUSS, 2012, p. 298). O objeto, o instrumento mais simples e humilde, valeria mais do que aquele tradicionalmente apreciado pela "civilização" europeia, com o seu culto do belo. "Uma lata deconserva dealimento caracteriza melhor a nossa sociedade do que a joia mais suntuosa ou que o selo mais raro." (MAUSS, 2012, pp. 86-87). ${ }^{5} \mathrm{O}$ médio, a casa pobre e não a rica, a regra e não a exceção, devem guiar o interesse do pesquisador na busca de documentos. As dicotomias belo/ feio, culturas alta/baixa ficam de fora do campo etnológico, o que, diga-se de passagem, permite o aprofundamento da desconstrução (iniciada pelos românticos no início do século XIX) da ideologia do belo estético.

Nessa valorização de objetos comuns em detrimento da representação realista e estética, podemos perceber também em que medida o olhar do etnólogo se aproxima da revolução artística que significaram as colagens, introduzidas pelo cubismo sintético e pelos dada e surrealistas. Como teorizou Walter Benjamin (2013, p. 87), pensando nessas colagens, ao introduzir elementos cotidianos vindos da indústria e da reprodução técnica, essas obras explodiam com o sistema de representação tradicional. Mauss desdobra nesse gosto pelo comum e banal a sua visão materialista, que o distanciou de seu tio e mestre Durkheim, que tendia a ver a religião e a espiritualidade como matrizes das sociedades. Mas, vale destacar a diferença, o argumento de Valéry que vimos vai justamente no sentido de destacar o "valor estético". Mauss e Bataille, por um lado, e Valéry, de outro, criticam o museu de pontos de vista extremamente opostos. Se este critica "Vênus transformada em documento" (VALÉRY, 196o, p. 1.293), aqueles vão justamente pensar a cultura como documento. Para Mauss, o etnólogo deveria tratar seus objetos inventariadoscomo "objetos-testemunhos", sendo que testemunho para ele tinha um sentido bem positivista de "piéces à conviction”, ou seja, de provas (MAUSS, 2012, p. 84). Esses momentos de testemunho dos produtos culturais também seriam comprovantes de sua visão muito avançada para a época, segundo a qual, como escreveu em 1931, em plena era dos fascismos e fundamentalismos puristas, "tudo é mistura, produto de influências díspares, resultado de fatores múltiplos. A própria Vênus de Milo não é pura" (p. 111).

5 "Une boîte de conserve caractérise mieux nos sociétés que le bijou le plus somptueux ou que le timbre le plus rare.”

Remate de Males, Campinas-SP, v.39, n.1, pp. 38-62, jan./jun. 2019 - 42 
Nathan Schlanger, editor dos ensaios de Marcel Mauss sobre técnica, que incluem muitas de suas discussões sobre o procedimento de coleta e de coleção em um acervo etnológico, chama a atenção para o fato de que não se pode deduzir do apego do etnólogo ao comum e banal, como no exemplo da lata de conserva, uma espécie de premonição da poética de Andy Warhol com suas Campbell soup. O mesmo argumento vale para distanciar também Mauss de Bataille (MAUSS, 2012, p. 88). Por outro lado, não é menos verdade que esse olhar etnológico passou a marcar cada vez mais nossa cultura e a produção artística, a ponto de podermos falar, hoje, de uma verdadeira virada etnológica nas artes. As obras de Mauss também ajudaram a formar essa cultura atenta às diferenças e que tem consciência da urgência de se revalorizar grupos que são esmagados pelo processo civilizatório intrinsecamente violento. Se a geração dele ainda alimentou a ideia da construção de museus-arquivos (dentro de uma competição entre as nações coloniais), suas ideias permitem, hoje, a desconstrução deles, sua "anarquivação", como costumo escrever.

Esse movimento tem gerado nas últimas duas décadas uma gigantesca crise nos museus, com sua matriz eurocêntrica e colonial. Atualmente a construção do Humboldt-Forum no Castelo de Berlim, que será inaugurado em breve, reunindo a coleção antes abrigada no Museu Etnológico de Dahlem e construída ao longo dos séculos XIX e XX, está pontuada por esses novos debates em torno do pós-colonial, que incluem a consciência acerca da violência colonial e das apropriações indevidas. Desde 2016 foi criada na Fundação da Herança Cultural Prussiana [Stiftung Preussischer Kulturbesitz], que administra esse projeto, a posição de um responsável por traçar a proveniência dos itens do acervo [Provenienzforschung] (PAPE, 2017, p. 7). Como Quatremère de Quincy, na passagem do século XVIII para o XIX, cada vez mais nos tornamos adeptos do localismo da cultura. A morte das grandes narrativas, detectada por Benjamin, após a Primeira Guerra Mundial, e por Jean-François Lyotard, após a Segunda grande guerra, tem como um de seus significados principais o declínio do universalismo abstrato (humanista e iluminista) e o reforço dos discursos locais. Associada a esse localismo, a virada icônica fez com que as hierarquias entre "arte europeia" e "objeto etnológico exótico" fossem abaladas, o que tem promovido, para além dos artistas-etnólogos, a porosidade entre os museus de arte e os de etnologia. Já Marcel Mauss (2012, p. 111) dizia, em seu artigo sobre Picasso, publicado na Documents, que existem "modestos conhecimentos sobre a arte dita primitiva, negra 
ou outra (que não é senão a arte tout court)”. Ele já afirmava em 1902 que "não existem povos não civilizados. Existem apenas civilizações diferentes. A hipótese do 'homem natural' está definitivamente abandonada” (p. 115). Esse mito do homem natural, criado pela Europa moderna, também derrete ao longo do século XX, abrindo caminho para a hibridação dos museus "naturais" e que continham a dita "grande arte".

\section{HETEROTOPIAS}

A mencionada relação entre museu e biblioteca destacada por Valéry evidentemente não ficou desapercebida depois pelo grande teórico dos arquivos e da arqueologia cultural que foi Foucault. Em seu texto de 1967, "Des espaces autres: heterotopies", ele faz uma história e tipologia desses contraespaços que seriam característicos de toda cultura, mas variam historicamente. No século XIX ele destaca o nascimento do cemitério do modo moderno, como o que conhecemos hoje, com jazigos individuais ou de família (que acompanhou o estabelecimento da "morte como doença”). Uma das características da heterotopia é sua capacidade de "justapor", exatamente o que incomoda a Valéry nos museus. Além disso, as heterotopias também recortam o tempo e são quase sempre também simultaneamente heterocronias. Infelizmente Foucault não percebe em que medida a fotografia constitui esse emaranhado de heterotopia e heterocronia, mas ele destaca justamente os museus e as bibliotecas como representantes dessas características por excelência nesse ponto. Vale a pena retomar o texto de Foucault (2009, p. 419):

De uma maneira geral, em uma sociedade como a nossa, heterotopia e heterocronia se organizam e se arranjam de uma maneira relativamente complexa. Há, inicialmente, as heterotopias do tempo que se acumula infinitamente, por exemplo, os museus, as bibliotecas; museus e bibliotecas são heterotopias nas quais o tempo não cessa de se acumular e de se encarapitar no cume de si mesmo, enquanto no século XVII, até o fim do século XVIII ainda, os museus e as bibliotecas eram a expressão de uma escolha individual. Em compensação, a ideia de tudo acumular, a ideia de constituir uma espécie de arquivo geral, a vontade de encerrar em um lugar todos os tempos, todas as épocas, todas as formas, todos os gostos, a ideia de constituir um lugar de todos os tempos que esteja ele próprio fora do tempo, e inacessível à sua agressão, o projeto de organizar assim uma espécie de acumulação perpétua e infinita do tempo em um lugar que não mudaria, pois bem, tudo isso pertence à nossa modernidade. O museu e a biblioteca são heterotopias próprias à cultura ocidental do século XIX. 
Como veremos, esse ideal acumulador se manterá, mas será radicalmente transformado na era do ciberespaço. Benjamin foi um dos primeiros a teorizar esse fenômeno que ele, no entanto, já localizava no Barroco, o que vem ao nosso encontro também, de nós barrocos latino-americanos. Ele observou em seu livro sobre o drama barroco alemão uma confluência entre esse acumular e uma determinada visão da escrita, imagética na qual o significante, diferentemente do que ocorre na escrita fonética, é carregado de sentido:

O ideal de saber do barroco, o armazenamento [Magazinierung], cujo monumento se cristalizou nas bibliotecas gigantes, é realizado pela imagem escrita [Schriftbild]. Quase como na China, é como se uma tal imagem fosse não signo do que deve ser sabido, mas, antes, um objeto em si mesmo digno de ser conhecido. Também aqui nesse aspecto a alegoria começou a recobrar consciência com os românticos (BENJAMIN, 1974, p. 359 ss.). ${ }^{6}$

Do barroco alemão ao barroquismo de Haroldo de Campos, percebe-se, aqui, que a distância não é tão vasta quanto se poderia pensar.

Ora, o que Valéry lamenta em seu texto é justamente esse caráter de acumulação, esse "encarapitar" obra sobre obra, a ausência da escolha individual, a ausência do espaço próprio, único, para uma obra ela mesma única. Daí ele concluir seu texto explicando esse mal-estar no museu com uma teoria da morte da mãe da Pintura e da Escultura: essa mãe se chamava Arquitetura (VALÉRY, 196o, p. 1.293). Lembrando o famoso conceito de Walter Benjamin, podemos dizer que Valéry sente falta da "aura" e do respeito a ela, ele admira a recepção solitária e contemplativa de obras e desdenha a recepção distraída e dispersiva, que leva, pare ele, à superficialidade. Benjamin e, mais próximo de nós, Vilém Flusser, vão elogiar essa superficialidade. Por outro lado, também arquitetos "estrela" se transformaram em especialistas na nova arquitetura de museus e na exacerbação da distração, como Frank Gehry e Daniel Libeskind. Ou seja, a arquitetura, se não morreu, transformou-se radicalmente e também contribuiu para a distração. Valéry, definitivamente, se opôs com bravura ao espírito do século XX.

6 "Das Wissensideal des Barock, die Magazinierung, deren Denkmal die riesige Büchersäle waren, wird in Schriftbild erfüllt. Fast gleich sehr wie in China ist es als ein solches Bild nicht Zeichen des zu Wissenden allein sondern wissenwürdiger Gegenstand selbst. Auch über diesen Zug kam die Allegorie mit den Romantikern zum Anfang einer Selbstbesinnung." 
Não é casual que esse último arquiteto, Libeskind, seja também um consagrado arquiteto de locais de memória e de reverência às vítimas das catástrofes genocidárias do século XX. Primeiro ele se tornou conhecido pela arquitetura do museu de Felix Nussbaum, em Osnabrück, e depois se tornou referência incontornável com seu Museu Judaico de Berlim. Ele também é o responsável pela torre que substituiu o World Trade Center em Nova York. Ou seja, o que vemos em Libeskind é uma clara relação entre arquitetura, memória, musealização e culto dos mortos. Voltando a Foucault: cemitérios (tal como os conhecemos hoje) e museus são invenções do século XIX e caracterizam a modernidade. O homem moderno tem uma outra relação com o tempo e com a morte: o museu, assim como a fotografia, como veremos melhor, são espaços heterotópicos de elaboração dessa nova realidade da vida como morte, e não mais como processo de transcendência. Entretanto, nossos museus não são os mesmos do século XIX e a questão, como veremos, é se o museu sobreviverá na era das imagens eletrônicas.

Daí também Theodor Adorno (2001) iniciar seu texto "Museu Valéry Proust", dedicado à análise desse pequeno manifesto antimuseu de Valéry - lembrando que o termo "museal" possui coloração desagradável em alemão, pois remete à conservação, e que, não por acaso, museu e mausoléu estão próximos em termos sonoros -. Ele arremata: "Os museus são como sepulcros de obras de arte, testemunham a neutralização da cultura. Neles são acumulados os tesouros culturais: o valor de mercado não deixa lugar para a felicidade da contemplação" (p. 173). Aqui soma-se à conservação e neutralização do já morto o elemento capitalista do valor de mercado.7 $\mathrm{O}$ importante é que, nesse texto, apesar de quase sempre ser citado apenas seu primeiro parágrafo, (como no influente ensaio de Douglas Crimp na October de 1980, “On the Museum's Ruins”), Adorno na verdade faz também uma leitura crítica de Valéry e contrapõe a ele uma deliciosa passagem de Proust, de seu A l'ombre des jeunes filles en fleurs, na qual lemos um rasgado elogio do espaço museal.

[...] nosso tempo, em todas as coisas, tem a mania de só querer mostrar aquilo de que se cerca na realidade, e, assim, suprimir o essencial, o ato do espírito que as isolou dessa realidade. "Apresenta-se" um quadro no meio de móveis, de bibelôs, de tapeçarias da mesma época, cenário insípido que a dona-de-

7 Essa relação entre culto dos mortos e capitalismo não deixa de nos remeter à tese benjaminiana do capitalismo como religião (de 1921[1991]), mas não vamos entrar por essa senda agora.

Remate de Males, Campinas-SP, v.39, n.1, pp. 38-62, jan./jun. 2019 - 46 
casa mais ignorante se esmera em armar, até à véspera, nos hotéis de hoje, passando agora seus dias nos arquivos e bibliotecas, cenário em meio ao qual a obra-prima que se contempla durante o jantar não provoca a mesma alegria embriagadora que só se lhe deve exigir numa sala de museu, a qual simboliza melhor, com sua nudez e seu despojamento de todas as particularidades, os espaços interiores em que o artista se abstraiu para criar (PROUST, 1994, p. 493).

Para Adorno, Valéry seria fiel às obras de arte, Proust ao próprio museu. O primeiro seria adepto do esteticismo da arte pela arte e teria como ideal a "obra pura", sonhada também por Mallarmé; já Proust seria, na sua relação com as obras, um amador que se deixa embalar pela memória involuntária na recepção delas. Ele tem muito mais a ver com o museu, pois sabe apreciar "o histórico como paisagem" (ADORNO, 2001, p. 181). Ele pensa a realidade embebida no tempo e na memória. Adorno cita e analisa: “'Ce qu'on appelle la postérité, c'est la postérité de l'oeuvre', frase - comenta Adorno - que poderíamos traduzir assim: o que se chama posteridade [Nachwelt], é a vida póstuma [Nachleben] das obras" (p. 181). Ou seja, Proust pensa o tempo como memória, sobrevivência, diria seu contemporâneo Aby Warburg (2010c, p. 374). Como resume Adorno (2001, p. 181), para Proust "nada tem consistência a não ser o que foi transmitido pela memória, o amor de Proust se apega mais a esta segunda vida [...] do que à primeira”. Aquilo que incomodava Valéry, o caos do museu, é visto por Proust dentro de uma dimensão trágica: "A morte das obras no museu, segundo Proust, desperta-as para a vida" (p. 181). Mas Adorno salva de cada um o seu momento de verdade: Valéry em seu apego teimoso à obra, Proust em seu apego à memória, ao sujeito e não à coisa, ou expressando-se de modo negativo: "A fetichização do objeto e a presunção do sujeito corrigem-se mutuamente. As posições se interpenetram uma na outra" (p. 183).

Mas Valéry (196o, p. 1.292), adiantando as pesquisas de Foucault, nota ainda em seu texto uma terrível tendência à musealização de tudo: "O museu exerce uma atração sobre tudo aquilo que os homens fazem. O homem que cria, o homem que morre, alimentam-no. Tudo acaba na parede ou na vitrine... Eu me recordo da figura da banca no jogo, que ganha todas as rodadas". Essa passagem pode ser lida, me parece, tanto com um potencial de historicização do museu (ele arquiva tudo em

8 "Le musée exerce une attraction constante sur tout ce que font les hommes. L'homme qui crée, l'homme qui meurt, l'alimentent. Tout finit sur le mur ou dans la vitrine... Je songe invinciblement à la banque des jeux qui gagne à tous les coups." 
uma espécie de enciclopédia viva-morta), ou também como desistoricização (ele destrói os contextos, mistura tudo). No entanto, Adorno (2001, p. 184) relê essa crítica com um olhar proustiano: "Somente a caminho da própria morte, e separadas do solo provedor, as obras se tornam plena promesse $d u$ bonheur". Sua conclusão enfatiza um tema frequente em sua obra, a leitura dos constructos artísticos como inscrição do sofrimento e da dor. Ou seja, ao invés de ver nessa formulação de Valéry uma tendência à desistoricização do dispositivo museu, ele, pelo contrário, ilumina a vertente em direção à inscrição do presente. E nota que as obras possuem agora "um novo conteúdo [Gehalt, teor] à medida que o sentido antigo se encolh[e]", elas se tornam agora "hieróglifos da história" (ADORNO, 2001, p. 185). Adorno pensou a arte "como escritura histórica", na medida em que ela é para ele "memória do sofrimento acumulado". "Mas que seria a arte enquanto historiografia, se ela se desembaraçasse da memória do sofrimento acumulado?” (ADORNO, 1973, p. 387; e 1982, p. 291), ele se perguntou. No seu ensaio "Aqueles anos vinte" [Jene zwanziger Jahre], lemos também: "Porque o mundo sobreviveu ao seu próprio naufrágio, ele precisa ainda da arte como a sua historiografia inconsciente" (1977, p. 506). ${ }^{9}$ Uma formulação proustiana com tons mais trágicos. E ele ainda arrematou: "Os autênticos artistas do presente são aqueles em cujas obras ressoa o terror mais radical” (p. 506). ${ }^{10} \mathrm{Na}$ era das catástrofes, a arte passa a ser pensada como arquivo histórico - proustianamente vinculado à noção de memória/escritura "involuntária”, a saber, inconsciente.

\section{MUSEU E ONTOTIPOLOGIA: A FABRICAÇÃO DO PRÓPRIO}

Paradoxalmente, essa atração de todas as obras para o ambiente do museu faz pensar também em um outro tema fundamental, quando se trata de repensar o museu hoje: a crise da modernidade e a passagem para a pós-história. Hans Belting (2014, p. 174), em sua obra de 1995, O fim da história da arte, refletindo sobre o novo museu e a exigência de ele dar respostas a um público "que quer ver no museu tudo o que os livros não explicam mais", nota, ao lado do tema benjaminiano da tendência à dispersão/distração desses espaços museais, que, se o museu tradicional

\footnotetext{
9 "Weil jedoch die Welt den eigenen Untergang überlebt hat, bedarf sie gleichwohl der Kunst als ihrer bewusslosen Geschichtsschreibung."

10 "Die autentischen Künstler der Gegenwart sind die, in deren Werken das äußerste Grauen nachzittert."
} 
quebrou "o poder do presente", permutando o tempo em história, na nossa sociedade de arquivos digitais e bancos de dados ocorre uma tendência à espetacularização, o evento substitui a obra (p. 182). Ou seja, diferentemente de Valéry e com Adorno, para Belting no museu o tempo é historicizado, mas, por outro lado, na era dos arquivos digitais, ele se torna "evento" atemporal.

Podemos pensar então que, se o historicismo do século XIX submetia o presente ao peso do passado, hoje as coisas se invertem: o agora faz do passado um bibelô de seu espetáculo. Estamos não tanto em um presentismo, como afirma François Hartog (2017), mas em um agorismo como já o determinara nos anos 1930 Walter Benjamin, com seu conceito de Jetztzeit, o tempo do agora, que deveria reger nosso relacionamento com o passado. Benjamin, vale destacar, viu na fotografia, e em seu tempo do disparo, o cânone do tempo pós-histórico (SELIGMANN-SILVA, 2016).

Ao notar a importância atual das curadorias, Belting não leva adiante em sua análise o fato de que ocorre também nesse processo um privilégio do conceitual sobre o imagético. Dá-se aí mais um desdobramento da multimilenar querela entre palavras e imagens, ou seja, o logocentrismo não abre mão de seu poder, mesmo depois da virada imagética ou icônica. Mas Belting tem toda razão ao articular a relação dos museus com os Estados, como um desdobramento do duo Igreja e religião na Idade Média.

Aqui é essencial lembrar que esse modelo de Estado, no entanto, está em crise. As artes, desde a Revolução Francesa, cumpriram também o papel de construção da identidade nacional, e os museus se tornaram um de seus templos centrais. Não por acaso, como Jean Luc Nancy e Philippe Lacoue-Labarthe, entre outros, o notaram, os estados-nação no século XVIII e XIX se formaram na Europa disputando quem seria o seguidor mais autêntico daqueles modelos que eram vistos como matriciais, ou seja, a Grécia e a Roma antigas. A querelle des anciens et des modernes, aberta no século XVII por Perrault, teve como seus últimos desdobramentos a construção de museus como verdadeiras ressurreições de Acrópoles. Napoleão se deixou coroar como um imperador romano e, no âmbito germânico, Winckelmann, o pai da história da arte, viria a construir a história da arte antiga como base para o desenvolvimento não só da cultura, mas do próprio Estado moderno. Ele decretou: "O único meio de nos tornarmos grandes e, se possível, inimitáveis é imitar os antigos" (WINCKELMANN, 1995 p. 14; e 1975, p. 40). O museu se coloca ao lado do Estado moderno como uma máquina "ontotipológica": ele 
forja seus tipos na fornalha do passado para, em seguida, delinear o perfil do próprio no presente. Ele desenha o círculo de fogo em torno do que é "próprio" e "comum" na nação. Quem não estiver dentro do círculo é o "outro", o estrangeiro, aquele que não merece o cobertor dos direitos, a casa e o sentimento de pertença. Marcel Mauss, como vimos acima, ao afirmar que "tudo é mistura", tentou resistir a esse fundamentalismo identitário que se desdobrou (e ainda o faz) em projetos genocidas.

Hoje, como é conhecido, ou seja, nas últimas três décadas pelo menos, esses modelos começaram a derreter: o Estado-nação foi abalado pela globalização e pelo domínio do capital financeiro internacional; por outro lado, o museu tendeu a abrir suas portas para outras linguagens e culturas que não a da nação. Os museus passaram, lentamente demais, é verdade, de máquinas coloniais e colonizadoras, para instrumentos de pós-colonização. A inscrição da violência e da dor, que antes se dava dentro de um fechado círculo do próprio e da nação, teve que se abrir para a sobrevivência do próprio museu. Ocorreu o que costumo chamar de virada testemunhal da cultura. Junto com a virada imagética, como Hal Foster notou ainda no século XX, deu-se assim uma virada antropológica (ou etnológica, que mencionei acima), e as ditas ciências humanas, juntamente com as artes, foram fecundadas pelo discurso da multiplicidade. Elas foram forçadas a ao menos colocar sob suspeita suas tradicionais práticas ontotipológicas.

\section{HISTÓRIA DA ESCRITA E A FOTOGRAFIA COMO AGENTE DA PÓS-HISTÓRIA}

Essa mudança ocorreu dentro de um processo de crise do logocentrismo, movimento que, segundo Vilém Flusser (1998), atingira seu apogeu no século XIX. A história cultural para ele é marcada por uma polaridade que a desdobra entre natureza e cultura: na história da humanidade, vista por Flusser como uma história da técnica e dos modos de comunicação, imagens e escrita se digladiam como meios em nossa tentativa de organizarmos a nossa existência. Pois, se para existir temos que sair de nós, as imagens têm, inicialmente, o propósito de nos representar o mundo. Elas seriam mapas, que, no entanto, teriam se transformado em biombos, e nós teríamos passado de utilizadores de imagens a cultuadores delas. Esse culto teria chegado a um ponto tal, descreve Flusser a nossa mito-história originária, que as imagens 
obtiveram um estatuto alucinatório, não podiam mais ser decifradas e tornaram-se mágicas.

\begin{abstract}
No segundo milênio a.C., esta alucinação alcançou o seu apogeu. Surgiram pessoas empenhadas na "rememoração" da função originária das imagens, que passaram a rasgá-las a fim de abrir a visão para o mundo concreto escondido pelas imagens. $\mathrm{O}$ método do rasgamento consistia em desfiar as superfícies das imagens em linhas e alinhar os elementos imagéticos. Eis como foi inventada a escrita linear (FLUSSER, 1998, p. 29).
\end{abstract}

Essa escrita linear introduziu, com o seu alinhamento, uma outra consciência da nossa relação com o tempo: “Tratava-se de transcodificar o tempo circular em linear, traduzir cenas em processos. Surgia assim a consciência histórica, consciência dirigida contra as imagens" (FLUSSER, 1998, p. 29). Essa consciência opera conforme as leis de causa e efeito. Essa passagem significou um aprofundamento da alienação do mundo, pois a escrita tenderia à conceptualização do mundo. Ou seja, Flusser afirma uma primeiridade das imagens com relação ao mundo concreto; já os textos estariam condenados a uma secundidade e se relacionariam com o mundo via "imagens rasgadas". A esse universo gramatológico corresponderia uma História que tentaria incessantemente traduzir imagens em textos, conceptualizando, "desmagicizando". E o auge dessa história das letras teria sido justamente o século XIX, o mesmo que deu nascimento às imagens técnicas, a saber, à fotografia (p. 31). Mas, se as imagens tradicionais apresentavam um grau de abstração com relação ao fenômeno concreto, as imagens técnicas implicam uma tripla abstração, pois passaram das imagens tradicionais (imagem-mundo) para o mundo conceitual (conceitos abstratos) para serem criadas novamente sob a forma de imagens (imagens técnicas). Parte-se, nesse percurso, da pré-história, passando-se pela história até atingir à pós-história.

\title{
A PÓS-HISTÓRIA E A DITADURA DAS CAIXAS PRETAS
}

É interessante notar como em Flusser esse momento pós-histórico está carregado de ambiguidades - que ecoam as ambiguidades das novas técnicas. Em seu livro Pós-história (FLUSSER, 2011), ele reflete criticamente sobre a história, partindo de sua Bodenlosigkeit [ausência de chão, de fundamento], ou seja, do resultado das catástrofes do século XX, ele, judeu nascido em Praga e que perdeu toda a sua família na Shoah. Nessa obra, detecta que predominaria no Ocidente um tipo de comunicação marcado pela hierarquia, verticalidade e direção única, que 
ele descreve como sendo os discursos. Estes se opõem aos diálogos. Esse diagnóstico o leva a falar de uma solidão na massa (2011, p. 73), o que estaria conduzindo a uma decomposição do tecido social, ideia atual até hoje, pese ou justamente devido à expansão monstruosa das redes sociais. Mas é nessas redes (melhor dizendo, nos seus antecessores) que Flusser apostava como meios de superação desse esgarçamento do tecido social. Ele valorizava a capilaridade das redes e a sua capacidade de traduzir discursos esotéricos da ciência em códigos acessíveis:

Os modelos não mais provêm do transcendente (do Reino das Ideias, de Deus), nem são "invenções" de homens geniais (técnicos, cientistas, políticos, filósofos, artistas). São resultados de combinações minuciosas de "bits" feitas por programadores, analistas de sistemas, e outros funcionários anônimos comparáveis. Tais modelos não evocam nem imagens divinas, nem visões inspiradas, mas mosaicos. Ou evocam, melhor ainda, ideogramas que funcionam (FLUSSER, 2011, p. 101).

Entretanto o resultado são o que ele denominou de caixas pretas, ou seja, dispositivos que resultam do saber de programadores, mas cuja utilização permanece um enigma para a massa, como ocorre com o aparelho fotográfico. Seus códigos são pobres, porém elas geram um trabalho gigantesco, inimaginável: se alimentam de toda a história e cospem pós-história. Eventos viram programas (FLUSSER, 2011, p. 77). Ou seja, se vimos com Valéry que a cultura se voltava para o museu, como uma máquina de (des)historicização, e, por outro lado, com Belting, vimos que o museu se volta agora para o evento, Flusser nota que "eventos viram programas”. O ideal seria, para ele, atingir nas redes diálogos circulares, como meio de se reinstituir a república, ou seja, o espaço público.

\section{TUDO VISA ETERNIZAR-SE EM IMAGEM TÉCNICA}

A filosofia de Flusser sobre a fotografia é uma teoria crítica das caixas pretas como dispositivos que nos programam na era pós-industrial:

[...] os aparelhos são caixas negras que simulam o pensamento humano, graças a teorias científicas, as quais, como o pensamento humano, permutam símbolos contidos na sua "memória", no seu programa. [...] no aparelho fotográfico e no fotógrafo já estão, como germes, contidas todas as virtualidades do mundo pós-industrial (FLUSSER, 1998, p. 48).

Desse novo triunfo das imagens resulta uma paradoxal relação com o tempo e a memória. Pois, se Flusser nota que a era pós-histórica, na qual 
imperam as imagens técnicas, justamente se despediu da ideia de história e da linearidade desta, permanece ainda um desejo, que poderíamos chamar de mágico, de eternização. Daí a passagem da história (escrita) para a memória imagética. $\mathrm{O}$ caminhar da cultura no sentido do museu, descrito por Valéry, é analisado agora como um deslocamento em direção às imagens técnicas, o que recoloca, para nós aqui, a proximidade possível entre as heterotopias museu e fotografia:

Tudo, atualmente, tende assim para as imagens técnicas: elas são a memória eterna de todo o empenho. Qualquer ato científico, artístico e político visa eternizar-se em imagem técnica, visa ser fotografado, filmado, videogravado. Como a imagem técnica é meta de qualquer ato, este deixa de ser histórico, passando a ser ritual de magia. Um gesto eternamente reconstituível segundo o programa. Com efeito, o universo das imagens técnicas vai-se estabelecendo como a plenitude dos tempos. E, apenas se considerada sob tal ângulo apocalíptico, é que a fotografia adquire os seus devidos contornos (FLUSSER, 1998, p. 38). ${ }^{11}$

É evidente o quanto esse processo se aprofundou hoje com as imagens digitais, que Flusser ainda praticamente desconhecia ao escrever esse texto. Ele percebera a virada que ocorrera: se no contexto do século XIX, para Mallarmé, ${ }^{12}$ o mundo parecia condenado a ser um livro e, logo depois, um museu para Valéry, ${ }^{13}$ agora ele se transformara em um gigantesco arquivo de imagens não mais analógicas, mas técnicas. Entretanto as imagens televisivas já indicavam essa tendência pantagruélica das imagens, de

11 Cf., no mesmo ensaio, embora de modo sucinto (FLUSSER, 1998, pp. 61-62).

12 Vale lembrar as belas imagens de Valéry (1957, pp. 653, 708) sobre o pensamento de Mallarmé: "A poesia, para ele, era, sem dúvida, o limite comum e impossível a que todos os poemas, e de fato todas as artes, tendem. [...] Ele viu nesta obra a ser feita o empreendimento essencial da humanidade, que ele disse de modo claro afirmando que tudo acabaria por ser expresso, que o mundo foi feito para culminar em um belo livro...”. Evidentemente que em Mallarmé havia também uma pulsão de explodir o livro no sentido de um encontro com as imagens. Benjamin foi um dos primeiros a descrever esse encontro de modo claro, antes dos concretistas. Cf. seu genial fragmento "Guarda-livros juramentado" de seu livro Rua de mão única: "Agora tudo indica que o livro, nessa forma tradicional, vai ao encontro de seu fim. Mallarmé, como viu em meio à cristalina construção de sua escritura, certamente tradicionalista, a imagem verdadeira do que vinha, empregou pela primeira vez no coup de dés as tensões gráficas do reclame na configuração da escrita” (BENJAMIN, 2012, p. 26). 13 Adorno (2001, p. 184) escreveu em seu ensaio sobre Valéry e Proust e o museu: "O processo que hoje delega ao museu a responsabilidade sobre toda e qualquer obra de arte, mesmo a mais recente escultura de Picasso, é irreversível. Esse processo não é apenas reprovável, como deixa prever um estado no qual a arte, ao consumar a sua própria alienação em relação aos objetivos humanos, 'retorna de novo à vida', conforme um verso de Novalis". Adorno, aqui, romanticamente reivindica a relação entre arte e vida, que o museu estaria bloqueando. Cf. Cusset (200o, p. 18), para um interessante comentário a essa passagem.

Remate de Males, Campinas-SP, v.39, n.1, pp. 38-62, jan./jun. 2019 - 53 
querer tudo sugar, como lemos nesta outra passagem, que mostra as imagens como gigantescas muralhas de uma represa que recebe e abraça todo o fluxo do tempo:

A história toda, política, arte, ciência, técnica, vai destarte sendo incentivada pelo aparelho, a fim de ser trancada no seu oposto: em programa televisionado. $\mathrm{O}$ aparelho se tornou a meta da história. Passa ele a ser represa do tempo linearmente progressivo. A plenitude dos tempos. História transcodada em programa torna-se eternamente repetível (FLUSSER, 2011, pp. 119-120).

Novamente essa figura da imagem como "plenitude dos tempos": a "paz perpétua” (que, ironicamente, Kant lembrou, é o sonho de um mundo sem guerras, mas também a plaqueta na porta do cemitério) é realizada pelas imagens técnicas que, como os museus, podem ser vistas como esse encontro paradoxal entre morte e vida, como Adorno o propôs. Mas agora há um achatamento ainda mais radical do tempo, e o passado se torna “aspecto do presente" (FLUSSER, 2011, p. 142). Em Benjamin (2013), como lemos em seu ensaio sobre a obra de arte na era de sua reprodutibilidade técnica, já se preconizava a articulação entre a fotografia, o fim da aura e o fim da tradição. ${ }^{14}$ Ele falava de um "abalo violento do que é transmitido", ou seja, do corte na tradição. Passando ao cinema, formulou essa "liquidação do valor de tradição na herança cultural” com palavras que decerto inspiraram Flusser:

Esse fenômeno é especialmente acessível nos grandes filmes históricos. Ele submete posições cada vez mais distantes ao seu domínio. E quando Abel Gance exclamou entusiasticamente em 1927: "Shakespeare, Rembrandt, Beethoven serão filmados... Todas as lendas, todas as mitologias e todos os mitos, todos os fundadores de religiões, e mesmo todas as religiões... aguardam sua ressurreição em celuloide, e os heróis precipitam-se aos portais", convidava, embora sem a intenção de fazê-lo, a uma liquidação generalizada (BENJAMIN, 2013, pp. 54-55).

Para Flusser (2011, p. 142), o tempo pós-industrial é o do presente como vórtice que suga passado e futuro, sendo que as imagens do passado são traduzidas em dois tipos de memória: as acessíveis e as recalcadas. Esse tempo estagnado impede também toda decisão e engajamento. $\mathrm{O}$

14 Também Marcel Mauss (2012, pp. 108 e 276), na sua luta contra os nacionalismos de face fundamentalista e fascista de sua época, reivindicou em seu artigo "La nation" (1920) uma reversão do olhar sobre a história: ao invés de vermos a nação como coroamento da tradição, deveríamos, ao contrário, aprender a ver a tradição como uma invenção da nação. Borges desdobrou esse tipo de visão pós-historicista para o campo da literatura.

Remate de Males, Campinas-SP, v.39, n.1, pp. 38-62, jan./jun. 2019 - 54 
aparelho rapta a vida e dá em troca apenas o tempo do tédio. Sentimos a vacuidade como face da experiência da morte, e, para Flusser, o mesmo aparelho que nos joga no tédio também vai nos distrair dele. Mas, nesse movimento, afirma um Flusser (p. 144) leitor de Sartre, o tédio permite desmascarar o funcionamento dos aparelhos.

As imagens aparecem como relâmpago e como relâmpago desaparecem. No entanto, são "eternas", porque guardadas em memórias, e também recuperáveis “imediatamente”. Logo, não há mais “o” espaço: todos estamos aqui juntos, não importa onde estejamos. Logo, não há mais “o” tempo: tudo está comigo agora, não importa quando tenha acontecido (FLUSSER, 2008, p. 149).

A história é superada em um alef cibernético, que apresenta a espaço-temporalidade concentrada de modo risomático e concentrado. Nesse supercérebro estetizado, as pessoas serão "formigas curiosas: secretarão arte em vez de ácido fórmico [...] e sobretudo viverão em orgasmo cerebral permanente" (FLUSSER, 2008, p. 131). E arremata, para nosso espanto: "Se isto for formigueiro, aceito o modelo" (pp. 127-131). Não existe mais, portanto, para ele, a possibilidade de um espaço heterotópico singular denominado museu. Para ele, toda a cultura se transforma em obra de arte e tende para um Gesamtkunstwerk [obra de arte total].

\section{TODOS SOMOS ARTISTAS AGORA: A CIDADE COMO GESAMTKUNSTWERK E O FIM DOS MUSEUS}

Essa construção da ideia de uma criatividade concreta em uma sociedade de artistas também pode ser acompanhada nos textos de Flusser especificamente voltados para as artes. Ele faz um elogio do trabalho artístico como uma obra que tende ao coletivo, como lemos em seu texto sobre a $18^{a}$ Bienal de São Paulo, de 1985 . A curadoria é pensada como a construção de um Gesamtkunstwerk, ainda que ele não empregue esse termo. "A estrutura tradicionalmente discursiva (o artista fala, o receptor escuta), cede lugar à estrutura dialógica (os artistas falam entre si para darem palavra final ao visitante). Criar tal espaço-tempo dialógico é o problema de toda criatividade futura." (FLUSSER, [s.d.1], p. 4). Já em seu artigo "Arte viva" ([s.d.2]), ele vai fazer uma defesa da união dos artistas com os geneticistas: na biotécnica o artista pode efetivamente auxiliar no novo design da vida. Arte e técnica se unem para pensar na vida como obra de arte total. 
A emancipação do caráter de objeto da arte, na visão de Flusser, a direciona no sentido da plasmação da vida e de seu meio: a cidade. Assim, ele pôde afirmar que "é a rua, e não a galeria, que distribui a arte atual, e a distribui fazendo participar o receptor, não relegando ele a papel passivo, como o faz a galeria" (FLUSSER, [s.d.3], p. 3). Podemos pensar no triunfo dos "modernos" diante dos "antigos" na mencionada querelle des anciens et des modernes: se Roma e as ruínas eram museus ao ar livre (impossíveis de serem transladados para a Europa), agora Flusser propõe que nossas cidades e a ciberpaisagem reintroduzem o museu como paisagem estetizada. $\mathrm{O}$ novo artista deve recodificar as mensagens da arte de elite e levá-las aos canais das massas, "portanto abandonar livros, exibições e concertos, e penetrar a TV, a produção industrial estereotipada e as ruas" ([s.d.5], p. 9). Para ele, o museu se torna supérfluo, portanto. O artista deve penetrar os modelos programados. Tornar-se programador. Desconstruir os modelos fascistas. Assim, é tão legítimo ele levar suas obras às ruas, como encarar suas obras e sua atuação como designer, em programas políticos ou mesmo no planejamento econômico ( [s.d.3], p. 4).

É na quarta de suas aulas no curso "Explicar a arte", que Flusser ministrou na Galeria Paulo Figueiredo, dedicado ao tema "Explicar o efeito político-social”, que seu ponto de vista sobre o papel revolucionário da arte fica mais claro. Se a primeira Revolução Industrial havia mantido a divisão entre o público e o privado, a segunda revolução, telemática, explode essa estrutura, já pelo simples fato de "reformular a estrutura da cidade" (FLUSSER, [s.d.4], p. 1). "A cidade pós-industrial, a cidade de fios [wired city], vai abolir a oscilação entre o espaço público e o privado. Vai instalar [a] rede comunicativa." (p. 1). Quando portas e janelas são substituídas por fios, é a própria consciência humana que está sendo transformada. Hegel deduzira da diferença entre o espaço privado e o público a consciência infeliz. Esse é um Leitmotiv na filosofia de Flusser, que recorda isso para mostrar o fim dessa situação. Pois esse espaço urbano/político de que Hegel partia foi radicalmente modificado. Também a diferença entre o fora e o dentro, necessária para manter o conceito de heterotopias, se esvai com essa descrição.

Se a modernidade lança seus habitantes no nomadismo (FLUSSER, 2011, p. 89) e na ruptura com suas origens (gerando a Bodenlosigkeit, ausência de chão e de fundamento), ela produz também uma libertação da pátria: a Heimatlosigkeit (2007, p. 223), ou seja, um feliz esquecimento da pátria, do lar, da origem, que nos amarrava de modo 
cego a mandamentos e preconceitos. A moradia que abandona o imóvel e se torna dinâmica já pode ser percebida nas mudanças de nossas casas: ele observa que as nossas paredes estão sendo vazadas por cabos que conectam o mundo em redes. Essa revolução informacional também abole a condição existencial que gerava a consciência triste. Não existe mais o interior das casas se opondo ao seu exterior. Agora o software vale mais do que o hardware. Esse sujeito da cidade telemática pode superar essa doença da alma. Enquanto artista, doravante ele "deverá imprimir seus modelos sobre os programas dos aparelhos. A sua matéria-prima não mais será o mundo objetivo, mas a cidade" ([s.d.4], p. 3).

Por outro lado, na medida em que o esquema que ordenava a política clássica era a divisão entre o espaço público e o privado, agora não há mais sentido falar em engajamento político. Na verdade "a arte passará a substituir-se à política, a qual não terá mais sentido em situação cibernetizada. O artista será o programador da cidade" (FLUSSER, [s.d.4], p. 3). Os centros programadores serão alimentados pelos artistas, de modo que "a cidade do futuro será a única 'obra de arte’: os artistas estarão empenhados na produção da cidade. Em tese, todos os cidadãos serão artistas. A cidade passará a ser a obra de arte de seus cidadãos, e neste sentido criativo será obra de consenso" (p. 4).

Flusser está consciente de que esse seu modelo é ambíguo e permite tanto pensar na cidade terrível de automação total e dominada pelos funcionários (reproduzida pela ficção científica ao menos desde Metrópolis, de Fritz Lang, 1926, até Blade Runner 2049, de 2017), como também pode ser a realização do mote da "l'imagination au pouvoir". Se não há mais espaço público para a troca de informações, nem esfera privada para criar as obras, só resta aos artistas serem os agentes da "única política possível” (FLUSSER, [s.d.4], p. 4). Andamos, portanto, na corda bamba entre a "pseudoarte do Kitsch programado" que leva a cidade a uma entropia final, e a "'bela cidade', a cidade na qual viver poderá significar opor a criatividade humana ao absurdo do mundo. O futuro da cidade", diz Flusser (p. 4), "está na mão da arte".

Após esse périplo pelo pensamento de Flusser e sua proposta de musealização do mundo, a lembrança da citação inicial deste texto, na qual Valéry revelava seu desgosto para com os museus, parece vinda de uma época muito antiga. Mas a verdade é que Flusser compartilha desse mal-estar de Valéry. Para ele, como vimos, os museus eram prisões de imagens, submetidas à batuta dos conceitos e dos livros. O fim dos museus é acompanhado pelo 
fim dos livros e pela nova consciência pós-histórica. Esses "fins" e "mortes", tão insistentemente preconizados na modernidade, devem ser confrontados, evidentemente, com o fato de que nunca produzimos e frequentamos tantos museus e livros como hoje. Mas a resposta de Flusser a essa objeção provavelmente seria que justamente a musealização da cultura, sua tradução em memória, se dá também pela via dessa hiperinflação de museus e livros que, como formas, estariam em seus estertores.

O flâneur proustiano também pode se sentir em parte realizado nessa nova paisagem contemporânea, na qual tudo é memória. Só que essa nova memória é paradoxal, pois sua temporalidade é achatada. Isso a torna antípoda da memória proustiana, eminentemente elegíaca, que reencantava o mundo ao iluminá-lo do ponto de vista póstero, dos que veem o tempo se inscrever nas nossas carnes e na carne do mundo. Proust fala a partir de um futuro do passado, e as novas mídias falam no instante de agora. O cemitério, que no século XIX, como notou Foucault, abandonou os centros das cidades, expulso para as periferias e tinha como companheiros de heterotopia a cultura livresca e museal, foi ainda mais marginalizado na era do ciberespaço. Nossa cultura - violenta e geradora de políticas da morte - é ainda mais tanatofóbica que a era da construção dos grandes museus-mausoléus nacionais.

Mas, para essa angústia, Flusser tem uma resposta que é interessante, para não dizer intrigante. Vimos que para Proust a posteridade é a vida póstuma das obras, assim como lembramos da noção-chave de Warburg da antiguidade como sobrevivência. Pois bem, para Flusser a posteridade é a sobrevivência de nossas memórias. Temos, diz ele, que reaprender a função da memória. A fotografia ele via como aniquilação da história e imposição de uma nova ideia de memorização:

A câmera mergulha na história, pega, corta cenas, contextos [...] e apanha esse contexto e transporta-o para o nível trans-histórico. Essa é a ideia de ser eternizado pela fotografia. Fotografia não é tanto uma testemunha da história, mas a destruição da história (FLUSSER, 2010, p. 25).

Ela, como vimos, semelhantemente ao museu, suga a história como um aspirador de pó. Por outro lado, Flusser procura conciliar esse fim da história - esse arrancar violento de toda ideia de contexto - com uma noção de memória que hora ele apresenta em termos culturais, hora de modo místico. Ele escreveu no texto "Memória", de 1988, que "ser homem é dispor de memória cultural, e na medida em que participamos da memória cultural, emancipamo-nos de nossa condição biológica 
('animalesca')" (FLUSSER, 1988, p. 1). Aqui parece estarmos distante do modelo do formigueiro cibernético. Mas o autor dizia também que sobrevivemos na memória dos outros. Ele escreve: “Talvez seja por isso que os judeus dizem sobre alguém falecido: 'Que a sua memória seja abençoada'. O que pode significar: 'Sou responsável por ele”' (2010, p. 32). Somos os responsáveis pela imortalidade dos outros, e essa memória constitui uma rede transumana de memórias. Como vimos em Adorno, quando ele escreve sobre Proust: "nada tem consistência, a não ser o que foi transmitido pela memória".

\section{A INVASÃO DA ARTE PELA VIDA}

Resta deixar acesa a admoestação de Flusser: o fim dos museus e o triunfo estético das cidades podem ser fascistas ou emancipadores. Tudo depende de nossa mobilização. Tudo depende de conseguirmos evitar que os "funcionários" detenham as rédeas dessa estetização da política. Com Benjamin e para além dele, podemos concluir: para que essa estetização não seja fascista, antes temos que politizar a arte. Essa politização levará a uma profunda reformulação daquilo que entendemos por arte. A arte, como, por exemplo, temos visto com o "artivismo", será cada vez mais invadida pela política, pela "vida". Artistas se transformam em agentes na política, em performers da memória crítica. A acima mencionada virada etnológica das artes, já anunciada por Marcel Mauss e Bataille, também faz parte desse movimento centrífugo em direção às diferenças, aos devires e transformações, em detrimento da arte clássica como triunfo da forma estanque, ontotipológica, centrípeta e que nos leva ao reino de Tânatos. Esses novos artistas, como bárbaros esclarecidos, transformam cada ato de respiração e cada centímetro da cidade em "espaço de ação". Ao introduzirem o princípio lúdico-crítico ali onde imperavam códigos de segmentação, hierarquização e repressão, eles podem ajudar a fazer saltar a estrutura que é responsável por manter as imagens prisioneiras em museus com seus cubos brancos. Caso consigam vencer as poderosas forças que querem amordaçar as artes e todo pensamento crítico, em um tempo não muito distante, o museu já será, de fato, uma "peça de museu".

\section{$\overline{\text { REFERENCIAS }}$}

ADORNO, Theodor W. Ästhetische Theorie. Frankfurt a.M.: Suhrkamp, 1973. 
ADORNO, Theodor W. Kulturkritik und Gesellschaft II. Eingriffe, Stichworte, Anhang. Gesammelte Schriften, v. 10.2. Org. por Rolf Tiedemann, com auxílio de Gretel Adorno, Susan Buck-Morss e Klaus Schulz. Frankfurt a.M.: Suhrkamp, 1977.

ADORNO, Theodor W. Teoria estética. Trad. Artur Mourão. Lisboa: Edições 70, 1982.

ADORNO, Theodor. Museu Valéry Proust. In: Prismas. Crítica cultural e sociedade. Trad. de Augustin Wernet e Jorge Almeida. São Paulo: Ática, 2001, pp. 173-185.

BATAILLE, Georges. Documents: Georges Bataille. Trad. J. C. Penna e M. J. Moraes. Desterro: Cultura e Barbárie, 2018.

BELTING, Hans. O fim da história da arte. São Paulo: Cosac e Naify, 2014.

BENJAMIN, Walter. Gesammelte Schriften. V. 1. Frankfurt a.M.: Suhrkamp, 1974.

BENJAMIN, Walter. Kapitalismus als Religion. In: Gesammelte Schriften, v. VI. Frankfurt a.M.: Suhrkamp, 1991, pp. 100-102.

BENJAMIN, Walter. Magia e técnica, arte e política: ensaios sobre literatura e história da cultura. 8. ed. rev. Trad. Sérgio Paulo Rouanet; revisão técnica de Márcio Seligmann-Silva. São Paulo: Brasiliense, 2012.

BENJAMIN, Walter. A obra de arte na era de sua reprodutibilidade técnica. Org. e apres. M. Seligmann-Silva; trad. Gabriel Valladão Silva. Porto Alegre: L\&PM, 2013.

CRIMP, Douglas. On the Museum's Ruins. October, v. 13, Summer, 1980, pp. 41-57.

CUSSET, Yves. Le musée: entre ironie et communication. Paris: Pleins Feux, 2000.

FLUSSER, Vilém. Memoria. 1988. Disponível em: <http://flusserbrasil.com/art292.pdf>. Acesso em: 9 maio 2017.

FLUSSER, Vilém. Ensaio sobre a fotografia. Para uma filosofia da técnica. Lisboa: Relógio d’Água, 1998.

FLUSSER, Vilém. Bodenlos: uma autobiografia filosófica. São Paulo: Annablume, 2007.

FLUSSER, Vilém. O universo das imagens técnicas. Elogio da superficialidade. São Paulo: Anna Blume, 2008.

FLUSSER, Vilém. We shall Survive in the Memory of Others. Köln: Verlag der Buchhandlung Walther König, 2010.

FLUSSER, Vilém. Pós-história: vinte instantâneos e um modo de usar. São Paulo: AnnaBlume, 2011.

FLUSSER, Vilém. A $18^{\text {a }}$ Bienal de S. Paulo, exemplo de espaço-tempo novo. [s.d.1]. Disponível em: <http://www.flusserbrasil.com/art62.pdf>. Acesso em: 12 maio 2016. 
FLUSSER, Vilém. Arte viva. [s.d.2]. Disponível em: <http://www.flusserbrasil.com/artı38. pdf>. Acesso em: 12 maio 2016.

FLUSSER, Vilém. Como explicar a arte. Explicar a distribuição. [s.d.3]. Disponível em: <http://www.flusserbrasil.com/art218.pdf>. Acesso em: 12 maio 2016.

FLUSSER, Vilém. Explicar a arte. Explicar o efeito político-social. [s.d.4]. Disponível em: <http://www.flusserbrasil.com/art220.pdf>. Acesso em: 12 maio 2016.

FLUSSER, Vilém. O papel da arte na ruptura cultural. [s.d.5]. Disponível em: <http:// www.flusserbrasil.com/art435.pdf>. Acesso em: 12 maio 2016.

FOUCAULT, Michel. Outros espaços. In: Estética: literatura e pintura, música e cinema (Ditos e escritos III). 2. ed. Rio de Janeiro: Forense Universitária, 2009, pp. 411-422.

HARTOG, François. Crer em história. Belo Horizonte: Autêntica, 2017.

HOLLIER, Denis. O valor de uso do impossível. In: BATAILLE, Georges. Documents: Georges Bataille. Trad. J. C. Penna e M. J. Moraes. Desterro: Cultura e Barbárie, 2018, pp. 3-35.

LÉVI-STRAUSS. Claude. Anthropologie structurale. Paris: Plon, 1958.

MAUSS, Marcel. Technique, technologie et civilisation. Ed. e pref. Nathan Schlanger. Paris: PUF, 2012.

PAPE, Elise. Postcolonial Debates in Germany - An Overview. African Sociological Review / Revue Africaine de Sociologie, v. 21, n. 2, 2017, pp. 2-14.

PROUST, Marcel. À sombra das moças em flor. Em busca do tempo perdido. Trad. Fernando Py. São Paulo: Ediouro, 1994.

QUINCY, Quatremère de. Lettres à Miranda sur le déplacement des monuments de l'art de l'Italie. Org. Édouard Pommier. Paris: Macula, 1989[1796].

SELIGMANN-SILVA. Márcio. Walter Benjamin e a fotografia como segunda técnica. Revista Maracanan, v. 12, n. 14, jan.-jun. 2016, pp. 58-74.

SELIGMANN-SILVA. Márcio. Physiognomia, paisagem ideal e ficção autobiográfica: a viagem à Itália de Goethe. In: O local da diferença. 2. ed. São Paulo: Editora 34, 2018, pp. 268-291.

VALÉRY, Paul. Je disais quelquefois à Stéphane Mallarmé... - Mallarmé. V. I. In: Euvres. Paris: Gallimard, 1957, pp. 644-66o; e 706-710. (Coll. Bibliothèque de la Pléiade)

VALÉRY, Paul. Le problème des musées. In: CEuvres. V. II. Paris: Gallimard, 196o, pp. 1.2901.293. (Coll. Bibliothèque de la Pléiade) 
WARBURG, Aby. Botticellis Geburt der Venus und Frühling. In: Werke. Frankfurt a.M.: Suhrkamp, 2010a[1893], pp. 39-123.

WARBURG, Aby. Dürer und die italienische Antike. In: Werke. Frankfurt a.M.: Suhrkamp, 2010b[1905], pp. 176-183.

WARBURG, Aby. Italienische Kunst und internationale Astrologie im Palazzo Schifanoja zu Ferrara. In: Werke. Frankfurt a.M.: Suhrkamp, 2010c[1912/1922], pp. 373-400.

WINCKELMANN. Johann Joachim. Reflexões sobre a Arte Antiga. Trad. Herbert Caro e Leonardo Tochtrop. Porto Alegre: Movimento, 1975.

WINCKELMANN. Johann Joachim. Von der Nachahmung der griechischen Werke in der Malerei und Bildhauerkunst. In: WINCKELMANN, Anton Raphael Mengs; HEINSE, Wilhelm. Frühklassizismus. Helmut Pfotenhauer et al. (orgs.). Frankfurt a.M.: Deutsche Klassiker Verlag, 1995, pp. 10-53.

Recebido: 21/01/2019

Aceito: 26/04/2019

Publicado: 1/07/2019

Remate de Males, Campinas-SP, v.39, n.1, pp. 38-62, jan./jun. 2019 - 62 